\title{
PENGARUH MODAL INTELEKTUAL DAN PROFITABILITAS TERHADAP NILAI PERUSAHAAN PADA BUMN DI INDONESIA
}

\author{
Budianto $^{1}$, Zainal Putra ${ }^{2}$, Eka Suci Wahyuni ${ }^{3}$ \\ 1,2 Universitas Teuku Umar, Meulaboh. [budianto@utu.ac.id] \\ ${ }^{3}$ Alumni Universitas Syiah Kuala, Banda Aceh
}

\begin{tabular}{|c|c|}
\hline INFO ARTIKEL & ABSTRAK/ABSTRACK \\
\hline $\begin{array}{l}\text { Histori Artikel : - } \\
\text { Tgl. Masuk : - } \\
\text { Tgl. Diterima : - } \\
\text { Tersedia Online : } 19 \text { desember } \\
2018\end{array}$ & $\begin{array}{l}\text { The main problem to be studied in this research is whether the } \\
\text { variable of intellectual capital and profitability give positive } \\
\text { influence in increasing company value in Indonesia Stock } \\
\text { Exchange (IDX). The purpose of this research is to test empirically } \\
\text { the influence of intellectual capital and profitability to company } \\
\text { value. The population in this research are State-owned }\end{array}$ \\
\hline $\begin{array}{l}\text { Keywords: } \\
\text { Firm Value, Intellectual Capital, } \\
\text { Profitability, BUMN }\end{array}$ & $\begin{array}{l}\text { Enterprises (BUMN) listed in Indonesia Stock Exchange in the year } \\
\text { of observation } 2014 \text { until } 2016 \text {. Total population are } 60 \\
\text { observation ( } 20 \text { companies } x 3 \text { years). Data used in this research } \\
\text { are balanced panel data. The analysis method that is applied in } \\
\text { this research is multiple regression analysis. The results of this } \\
\text { research show that simultaneously intellectual capital and } \\
\text { profitability have an effect to firm value. Partially, intellectual } \\
\text { capital has a positive but not significant effect to firm value, } \\
\text { while profitability have a positive and significant effect to firm } \\
\text { value. }\end{array}$ \\
\hline
\end{tabular}

\section{PENDAHULUAN}

Salah satu tujuan perusahaan adalah memaksimalkan nilai pemegang saham. Nilai pemegang saham akan meningkat apabila nilai perusahaan meningkat yang ditandai dengan tingkat pengembalian investasi yang tinggi pada pemegang saham. Menurut Soliha dan Taswan (2002) nilai perusahaan yang tinggi menjadi keinginan pemilik perusahaan, sebab dengan nilai perusahaan yang tinggi menunjukkan kemakmuran pemegang saham juga tinggi. Untuk mencapai tujuan perusahaan, manajer membuat keputusan investasi yang menghasilkan net present value (NPV) positif.

Modal intelektual menunjukkan sumber daya pengetahuan dalam bentuk karyawan, pelanggan, proses atau teknologi yang dapat digunakan untuk membantu menciptakan nilai dan meningkatkan keunggulan kompetitif perusahaan. Penciptaan nilai bagi perusahaan adalah ketika perusahaan mampu menghasilkan sesuatu yang lebih dari sumber daya yang diinvestasikan. Dengan kata lain, apabila perusahaan mampu mengelola dan memanfaatkan sumber daya yang dimiliki sehingga sumber daya tersebut dapat menciptakan value added bagi perusahaan, maka hal ini disebut sebagai value creation (Ulum, 2008).

Setiap perusahaan yang terdaftar di Bursa Efek Indonesia (BEI) menginginkan harga saham yang dijual memiliki potensi harga tinggi dan menarik minat para investor untuk membelinya. Hal ini dikarenakan, semakin tinggi harga saham, maka akan semakin tinggi nilai perusahaan tersebut. Nilai perusahaan dapat menggambarkan keadaan perusahaan. Dengan baiknya nilai perusahaan maka perusahaan akan dipandang baik oleh para investor, calon investor, kreditor dan calon kreditor, demikian pula dengan nilai perusahaan yang tinggi menunjukkan kinerja perusahaan yang baik.

Modal intelektual juga dijelaskan dalam PSAK No.19 (revisi 2009) tentang aktiva tidak berwujud. Dalam PSAK No. 19 (revisi 2009) disebutkan bahwa aktiva tidak berwujud adalah aset non-moneter yang dapat 
diidentifikasi tanpa wujud fisik. Beberapa contoh dari aktiva tidak berwujud telah disebutkan dalam PSAK No. 19 (revisi 2009) antara lain ilmu pengetahuan dan teknologi, desain dan implementasi sistem atau proses baru, lisensi, hak kekayaan intelektual, pengetahuan mengenai pasar dan merek dagang (termasuk merek produk dan judul publisitas), (PSAK No.19, Revisi 2009).

Dalam praktiknya perusahaanperusahaan di Indonesia belum memberikan perhatian yang lebih terhadap ketiga komponen modal intelektual yaitu human capital, structural capital, dan capital employeed. Agar dapat bersaing dalam era knowledge based business, ketiga komponen modal intelektual tersebut diperlukan untuk menciptakan value added bagi perusahaan (Sawarjuwono dan Kadir, 2005). Perusahaanperusahaan di Indonesia cenderung menggunakan conventional based dalam membangun bisnisnya sehingga produk yang dihasilkan masih miskin kandungan teknologinya.

Hasil penelitian yang dilakukan Wahyuni (2013) pada perusahaan manufaktur di BEI menemukan bahwa modal intelektual berpengaruh positif terhadap nilai perusahaan. Randa dan Solon (2012) juga menemukan bahwa modal intelektual berpengaruh positif terhadap nilai perusahaan. Putra (2012) meneliti pengaruh modal intelektual terhadap nilai perusahaan perbankan di BEI menemukan bukti bahwa modal intelektual berpengaruh positif terhadap nilai perusahaan.

Chen et al., (2005) menggunakan data dari perusahaan listing di Taiwan, membuktikan bahwa modal intelektual berpengaruh positif terhadap market value dan kinerja keuangan, dan dapat digunakan sebagai indikator kinerja keuangan masa depan. Sementara itu Yuniasih et al., (2010) meneliti pengaruh modal intelektual terhadap kinerja pasar perusahaan manufaktur yang terdaftar di BEI. Kinerja pasar diukur dengan rasio price to book value (PBV), hasilnya adalah modal intelektual tidak berpengaruh pada kinerja pasar.

Selain modal intelektual, profitabilitas juga merupakan salah satu faktor lain yang dapat menjelaskan variasi dari nilai perusahaan. Profitabilitas memberikan nilai yang objektif mengenai nilai investasi pada sebuah perusahaan. Oleh karena itu profit sebuah perusahaan merupakan harapan bagi investor.

Hasil penelitian Sujoko dan Soebiantoro (2007) menjelaskan bahwa profitabilitas yang tinggi menunjukkan prospek perusahaan baik, sehingga para investor akan merespon positif sinyal tersebut, sehingga harga saham dan nilai perusahaan meningkat. Soliha dan Taswan (2002) dalam penelitiannya memberikan bahwa profitabilitas berpengaruh positif dan signifikan terhadap nilai perusahaan.

Hasil penelitian lain yang dilakukan oleh Jusriani dan Raharjo (2013) menunjukkan bahwa variabel profitabilitas (ROE) memiliki pengaruh positif yang signifikan terhadap nilai perusahaan. Ayuningtias dan Kurnia (2013) juga melakukan penelitian yang memberikan hasil bahwa profitabilitas terbukti berpengaruh positif terhadap nilai perusahaan.

Berdasarkan pemaparan di atas, maka tujuan penelitian ini adalah untuk menguji pengaruh modal intelektual dan profitabilitas secara parsial dan simultan terhadap nilai perusahaan. Rumusan masalah dalam penelitian ini adalah, apakah modal intelektual dan profitabilitas berpengaruh positif terhadap nilai perusahaan.

\section{KERANGKA TEORITIS DAN PENGEMBANGAN HIPOTESIS}

\section{Modal Intelektual}

Bontis et al., (2000) menyatakan pada umumnya para peneliti membagi modal intelektual menjadi tiga komponen, yaitu: human capital, structural capital, dan capital employeed. Selanjutnya, secara sederhana human capital mencerminkan individual knowledge stock suatu organisasi yang dipresentasikan oleh karyawannya. Human capital ini termasuk kompetensi, komitmen dan loyalitas karyawan terhadap perusahaan.

Sawarjuwono dan Kadir (2005) menyatakan bahwa metode pengukuran modal intelektual dikelompokan menjadi dua 
kelompok yaitu: pengukuran non-monetary dan pengukuran monetary. Salah satu metode pengukuran modal intelektual dengan penilaian non-moneter yaitu Balanced Scorecard, sedangkan metode pengukuran modal intelektual dengan penilaian moneter, salah satunya yaitu model Pulic yang dikenal dengan sebutan value added intelektual capital (VAIC).

VAIC adalah metode yang dikembangkan oleh Pulic (1998), untuk menyajikan informasi tentang efisiensi nilai tambah dari aset berwujud (tangible asset) dan aset tak berwujud (intangible asset) yang dimiliki oleh perusahaan (Ulum, 2008). Proses value creation dipengaruhi oleh efisiensi dari Capital Employed, Human Capital, dan Structural Capital (Ulum, 2008).

a. Value Added of Capital Employed adalah indikator untuk value added yang diciptakan oleh satu unit dari physical capital. Ulum (2008) mengasumsikan bahwa jika 1 unit dari capital employed menghasilkan return yang lebih besar dari pada perusahaan yang lain, maka berarti perusahaan tersebut lebih baik dalam memanfaatkan Capital Employed.

b. Value added human capital menunjukan berapa banyak value added dihasilkan dengan dana yang dikeluarkan untuk tenaga kerja. Hubungan value added dan human capital mengindikasikan kemampuan human capital menciptakan nilai di dalam perusahaan.

c. Structural Capital Value Added menunjukkan kontribusi structural capital dalam penciptaan nilai. Structural Capital Value Added mengukur jumlah SC yang dibutuhkan untuk menghasilkan 1 rupiah dari value added dan merupakan indikasi bagaimana keberhasilan structural capital dalam penciptaan nilai.

\section{Profitabilitas}

Profitabilitas adalah kemampuan perusahaan untuk menghasilkan laba dari kegiatan operasionalnya. Semakin tinggi laba, makin tinggi return yang diperoleh investor. Perolehan laba merupakan ukuran keberhasilan kinerja keuangan perusahaan. Rasio profitabilitas merupakan rasio yang menunjukkan profitabilitas dalam kaitannya dengan penjualan dan investasi. Bersamasama, rasio-rasio ini akan menunjukkan efektivitas operasional keseluruhan perusahaan. Rasio profitabilitas diantaranya gross profit margin, net profit margin, return on equity, dan return on investment.

\section{Nilai Perusahaan}

Nilai perusahaan dalam penelitian ini diukur menggunakan Price to Book Value (PBV). PBV menggambarkan seberapa besar pasar menghargai nilai buku saham suatu perusahaan. Semakin tinggi rasio PBV, menunjukkan bahwa pasar semakin percaya akan prospek perusahaan tersebut. Secara konseptual, $P B V$ yaitu perbandingan antara harga saham dengan nilai buku per saham. Adapun yang dimaksud dengan nilai buku per saham (book value per share) adalah perbandingan antara modal dengan jumlah saham yang beredar.

Berdasarkan penjelasan diatas dapat diartikan bahwa $P B V$ sebagai hasil perbandingan antara harga pasar saham dengan nilai buku. PBV juga dapat berarti rasio yang menunjukkan apakah harga saham yang diperdagangkan overvalued (diatas) atau undervalued (dibawah) nilai buku saham tersebut. Hasil penelitian menyimpulkan bahwa rasio $P B V$ sangat berguna untuk menentukan saham-saham apa saja yang mengalami undervalued, overvalued, atau wajar, sehingga dapat menentukan strategi investasi yang sesuai dengan harapan investor untuk memperoleh dividen dan capital gain yang tinggi.

\section{Pengaruh Modal Intelektual terhadap Nilai} Perusahaan

Setiap usaha penciptaan nilai (value creation) diperlukan pemanfaatan seluruh potensi sumber daya yang dimiliki perusahaan. Potensi tersebut meliputi karyawan (human capital), aset fisik (physical capital) dan structural capital. Value added yang dihasilkan dari proses value creation akan menciptakan keunggulan kompetitif bagi perusahaan. Dengan memiliki keunggulan kompetitif, maka persepsi pasar terhadap nilai perusahaan akan meningkat karena diyakini bahwa perusahaan yang memiliki keunggulan kompetitif mampu 
bersaing dan bertahan di lingkungan bisnis yang dinamis.

Chen et al., (2005) yang meneliti hubungan antara modal intelektual dengan nilai pasar dan kinerja keuangan perusahaan yang menggunakan model Pulic (VAIC) dengan sampel perusahaan publik di Taiwan tahun 1992-2002 menunjukkan bahwa modal intelektual berpengaruh positif terhadap nilai pasar dan kinerja keuangan. Hasil penelitian yang dilakukan oleh Wahyuni (2013) menemukan bahwa modal intelektual berpengaruh positif signifikan terhadap nilai perusahaan. Randa dan Solon (2012), dan Putra (2012) juga menunjukan hasil bahwa modal intelektual berpengaruh positif terhadap nilai perusahaan.

\section{Pengaruh Profitabilitas terhadap Nilai Perusahaan}

Sujoko dan Soebiantoro (2007) menyatakan bahwa profitabilitas yang tinggi menunjukkan prospek perusahaan yang baik, sehingga investor akan merespon positif sinyal tersebut dan nilai perusahaan akan meningkat. Hal tersebut dapat dipahami karena perusahaan yang berhasil membukukan laba yang meningkat, mengindikasikan perusahaan tersebut mempunyai kinerja yang baik, sehingga dapat menciptakan sentimen positif para investor dan dapat membuat harga saham perusahaan meningkat. Meningkatnya harga saham di pasar dapat meningkatkan nilai perusahaan. Berdasarkan pernyataan tersebut dapat dikatakan bahwa profitabilitas mempunyai pengaruh positif terhadap nilai perusahaan.

Hasil penelitian Jusriani dan Raharjo (2013) menunjukkan bahwa variabel profitabiltas memiliki pengaruh positif dan signifikan terhadap nilai perusahaan. Penelitian yang sama juga dilakukan oleh Ayuningtias dan Kurnia (2013) mengenai pengaruh profitabilitas terhadap nilai perusahaan yang memberikan hasil bahwa profitabilitas berpengaruh positif terhadap nilai perusahaan. Penelitian Soliha dan Taswan (2002) serta Sujoko dan Soebiantoro (2007) juga menemukan bukti profitabilitas berpengaruh positif terhadap nilai perusahaan. Sementara itu Wahyuni (2013) menemukan bukti bahwa profitabilitas berpengaruh positif namun tidak signifikan terhadap nilai perusahaan.

Hipotesis

Adapun hipotesis yang diajukan dalam penelitian ini adalah:

1. Modal intelektual berpengaruh positif terhadap nilai perusahaan pada perusahaan BUMN yang terdaftar di Bursa Efek Indonesia.

2. Profitabilitas berpengaruh positif terhadap nilai perusahaan pada perusahaan BUMN yang terdaftar di Bursa Efek Indonesia.

\section{METODOLOGI PENELITIAN Populasi}

Yang menjadi populasi dalam penelitian ini adalah perusahaan BUMN yang terdaftar di Bursa Efek Indonesia pada periode pengamatan tahun 2014 sampai dengan 2016. Jumlah elemen populasi penelitian sebanyak 20 perusahaan. Periode pengamatan selama tiga tahun, dengan jumlah elemen populasi menjadi 60 pengamatan (20 perusahaan dikali 3 tahun). Karena elemen populasi tidak banyak, penelitian ini menggunakan metode sensus, yaitu semua elemen populasi diteliti.

\section{Sumber dan Teknik Pengumpulan Data}

Sumber data yang digunakan dalam penelitian ini adalah data sekunder yaitu laporan keuangan dan laporan tahunan yang memuat modal intelektual dan profitabilitas selama tahun 2014 sampai dengan 2016. Pengumpulan data tersebut diperoleh dari situs resmi Bursa Efek Indonesia www.idx.co.id.

\section{Definisi Operasional Variabel}

Adapun definisi operasional variabel akan dijelaskan sebagai berikut:

\section{1) Modal Intelektual $\left(X_{1}\right)$}

Modal intelektual adalah informasi dan pengetahuan yang diaplikasikan dalam pekerjaan untuk menciptakan nilai. Value Added Intellectual Coefficient (VAIC). Skala menggunakan rasio.

VAIC $=$ VACA + VAHU + STVA

\section{2) Profitabilitas $\left(X_{2}\right)$}


Profitabilitas diproksi melalui Return on Investment (ROA), yaitu perbandingan antara laba setelah pajak dengan total aset perusahaan. Skala menggunakan rasio.

ROA $=\frac{\text { Laba Bersih }}{\text { Total Asset }} \times 100 \%$

\section{3) Nilai Perusahaan ( $Y$ )}

Nilai perusahaan diukur dengan price to book value (PBV). Rasio PBV merupakan perbandingan antara harga saham dengan nilai buku ekuitas. Skala menggunakan rasio.

\section{$P B V=\frac{\text { Harga Penutupan Saham }}{\text { Nilai Buku per Lembar Saham }}$}

Metode Analisis Data

Penelitian ini menggunakan model regresi berganda untuk menguji dan menganalisis pengaruh modal intelektual dan profitabilitas terhadap nilai perusahaan pada perusahaan BUMN yang terdaftar di BEI yang diolah dengan program SPSS versi 21 . Model analisis regresi berganda diformulasikan sebagai berikut:

$$
\mathbf{Y}_{\mathrm{it}}=\alpha+\beta_{1} \mathbf{X}_{1 \mathrm{it}}+\beta_{2} \mathbf{X}_{2} \text { it }+\varepsilon_{\mathrm{it}}
$$

Keterangan:

$\mathrm{Y}_{\mathrm{it}} \quad=$ Nilai perusahaan $\mathrm{i}$ pada tahun $\mathrm{t}$

$\alpha \quad=$ Konstanta

$\beta_{1} ; \beta_{2}=$ Koefisien regresi

$\mathrm{X}_{1 \text { it }}=$ Modal intelektual perusahaan $\mathrm{i}$ pada tahun $\mathrm{t}$

$\mathrm{X}_{2 \text { it }}=$ Profitabilitas perusahaan $\mathrm{i}$ pada tahun $\mathrm{t}$

$\varepsilon_{\text {it }} \quad=$ error

\section{Rancangan Pengujian Hipotesis}

Untuk menguji hipotesis pertama $\left(\mathrm{H}_{1}\right)$ dan kedua $\left(\mathrm{H}_{2}\right)$ secara simultan terhadap variabel dependen (Y), maka digunakan uji simultan sebagai berikut:

$\mathbf{H}_{01}$ : $\beta_{1}=\beta_{2}=0 ;$ modal intelektual dan profitabilitas secara simultan tidak berpengaruh terhadap nilai perusahaan.

$\mathbf{H}_{\mathrm{a} 1}$ : Sekurang-kurangnya ada satu $\beta_{\mathrm{i}} \neq 0$, $i=1,2,3$; modal intelektual dan profitabilitas secara simultan berpengaruh terhadap nilai perusahaan.

Selanjutnya untuk menguji apakah variabel independen (X) berpengaruh terhadap variabel dependen $(\mathrm{Y})$ secara parsial digunakan uji parsial sebagai berikut:

$\mathrm{H}_{01}: \quad \beta_{1} \leq 0$; modal intelektual tidak berpengaruh positif terhadap nilai perusahaan.

$H_{a 1}: \beta_{1}>0$; modal intelektual berpengaruh positif terhadap nilai perusahaan.

$\mathrm{H}_{02}: \beta_{1} \leq 0$; profitabilitas tidak berpengaruh positif terhadap nilai perusahaan.

$H_{a 2}: \beta_{2}>0$; profitabilitas berpengaruh positif terhadap nilai perusahaan.

\section{HASIL DAN PEMBAHASAN}

Uji Normalitas

Pengujian normalitas dilakukan menggunakan uji Kolmogorov-Smirnov. Residual berdistribusi normal apabila tingkat signifikansinya menunjukkan nilai yang lebih besar dari 0,05. Berdasarkan uji KolmogorovSmirnov diperoleh Asymp. Sig. (2-tailed) sebesar 0,931 yang lebih besar dari 0,05. Hal ini menunjukkan bahwa residual berdistribusi normal. Hasil uji normalitas dapat dilihat di bawah ini:

Tabel 1.

Hasil Uji Normalitas

\begin{tabular}{|c|c|c|}
\hline \multicolumn{3}{|c|}{ One-Sample Kolmogorov-Smirnov Test } \\
\hline & & $\begin{array}{l}\text { Unstandardized } \\
\text { Residual }\end{array}$ \\
\hline \multicolumn{2}{|l|}{$\mathrm{N}$} & 49 \\
\hline \multirow{2}{*}{$\begin{array}{l}\text { Normal } \\
\text { Parameters }\end{array}$} & Mean & .0000000 \\
\hline & Std. Deviation & .53925278 \\
\hline \multirow{3}{*}{$\begin{array}{l}\text { Most Extreme } \\
\text { Differences }\end{array}$} & Absolute & .077 \\
\hline & Positive & .077 \\
\hline & Negative & -.051 \\
\hline \multicolumn{2}{|c|}{ Kolmogorov-Smirnov Z } & .542 \\
\hline \multicolumn{2}{|c|}{ Asymp. Sig. (2-tailed) } & .931 \\
\hline
\end{tabular}

Sumber: data diolah (2017)

Uji Multikolinearitas

Uji multikolinearitas bertujuan untuk melihat ada tidaknya korelasi antara variabelvariabel bebas. Untuk menguji ada tidaknya multikolinearitas dapat dilihat dari nilai toleransi atau VIF (variance inflation factor). Jika nilai Tolerance lebih dari 0,1 atau nilai VIF kurang 10 maka hal tersebut menunjukkan tidak terjadi multikolinearitas. Berdasarkan uji multikolinearitas variabel independen mempunyai nilai Tolerance 0,846 >0,1 dan nilai VIF $1,182<10$. Sehingga dapat disimpulkan bahwa tidak terjadi multikolinearitas antara variabel bebas dalam 
model regresi ini. Hasil uji multikolinearitas dapat dilihat sbb:

Tabel 2.

Hasil Uji Multikolinearitas

\begin{tabular}{|l|l|r|r|}
\hline \multirow{2}{*}{ Model } & \multicolumn{2}{|c|}{ Collinearity Statistics } \\
\cline { 3 - 4 } \multicolumn{2}{|l}{1} & Tolerance & \multicolumn{1}{c|}{ VIF } \\
\hline \multirow{2}{*}{1} & Modal Intelektual & .846 & \\
\cline { 2 - 4 } & Profitabilitas & .846 & 1.182 \\
\hline
\end{tabular}

Sumber: data diolah (2017)

\section{Uji Heteroskedastisitas}

Uji heteroskedastisitas bertujuan menguji apakah terjadi ketidaksamaan variance dari residual suatu pengamatan ke pengamatan yang lain. Untuk mendeteksi heteroskesdastisitas digunakan Uji Glejser. Jika variabel bebas tidak berpengaruh terhadap variabel terikat (absolut residual) maka tidak terjadi heteroskesdastisitas. Berdasarkan hasil uji glejser diperoleh tidak ada satupun variabel bebas yang berpengaruh signifikan. Hal ini dapat dilihat dari nilai signifikansi yang semuanya menunjukkan nilai Sig. di atas 0,05 (>0,05). Hasil uji heteroskedastisitas dapat dilihat pada tabel berikut ini:

\section{Tabel 3.}

Hasil Uji Heteroskedastisitas

\begin{tabular}{|c|c|c|c|c|c|c|}
\hline \multirow{2}{*}{\multicolumn{2}{|c|}{ Model }} & \multicolumn{2}{|c|}{$\begin{array}{l}\text { Unstandard } \\
\text { Coefficients }\end{array}$} & \multirow{2}{*}{$\begin{array}{c}\begin{array}{c}\text { Std. } \\
\text { Coeffi }\end{array} \\
\text { Beta }\end{array}$} & \multirow[t]{2}{*}{$\mathrm{t}$} & \multirow[t]{2}{*}{ Sig. } \\
\hline & & B & $\begin{array}{l}\text { Std. } \\
\text { Error }\end{array}$ & & & \\
\hline \multirow{3}{*}{1} & (Constant) & .619 & .356 & & 1.740 & .089 \\
\hline & $\begin{array}{l}\text { Modal } \\
\text { Intelektual }\end{array}$ & -.131 & .173 & -.121 & -.760 & .451 \\
\hline & Profit & .017 & .067 & .041 & .258 & .797 \\
\hline
\end{tabular}

Sumber: data diolah (2017)

\section{Uji Autokorelasi}

Uji autokorelasi bertujuan untuk menguji apakah dalam model regresi terdapat korelasi antara kesalahan pengganggu pada pengamatan dengan melihat perhitungan Durbin Watson (DW Test). Berdasarkan pengujian DW Test dalam penelitian ini pada tingkat keyakinan sebesar 95 persen telah terjadi autokorelasi positif. Untuk mengatasi hal tersebut maka harus dilakukan Uji Run Test agar terhindar dari autokorelasi.

Berdasarkan hasil Uji Run Test diperoleh nilai Asymp. Sig. (2-tailed) sebesar 0,561 lebih besar dari 0,05 (0,561 >0,05). Maka dapat disimpulkan bahwa tidak terdapat gejala autokorelasi. Dengan demikian, masalah autokorelasi yang tidak dapat terselesaikan dengan Durbin Watson dapat teratasi melalui uji Run Test sehingga model ini layak digunakan untuk analisis selanjutnya. Uji autokorelasi dapat dilihat pada Tabel 4.

Tabel 4.

Hasil Uji Autokorelasi

\begin{tabular}{|l|r|}
\hline \multicolumn{2}{|c|}{ (Runs Test) } \\
\hline & \multicolumn{1}{|c|}{$\begin{array}{c}\text { Unstandardized } \\
\text { Residual }\end{array}$} \\
\hline Test Value $^{\mathrm{a}}$ & .01085 \\
\hline Cases < Test Value & 24 \\
\hline Cases >= Test Value & 25 \\
\hline Total Cases & 49 \\
\hline Number of Runs & 28 \\
\hline Z & .581 \\
\hline Asymp. Sig. (2-tailed) & .561 \\
\hline
\end{tabular}

Sumber: data diolah (2017)

Analisis Deskriptif

Berdasarkan pengujian statistik deskriptif dapat dilihat sebaran nilai terendah, tertinggi, rata-rata dan standar deviasi dari variabel yang diteliti pada tahun 2014-2016. Variabel dependen nilai perusahaan (NP) diperoleh nilai rata-rata sebesar 0,7859 dengan standar deviasi sebesar 0,61389. Nilai tersebut menunjukkan bahwa rata-rata perolehan nilai perusahaan yang diukur dengan rasio PBV (price book value) adalah sebesar 0,7859 atau 78,59\%. Artinya rata-rata perusahaan BUMN yang terdaftar di BEI memiliki nilai perusahaan yang cukup baik.

Variabel independen modal intelektual (MI) diperoleh nilai rata-rata sebesar 1,2212 dengan standar deviasi sebesar 0,32467. Nilai tersebut menunjukkan bahwa selama periode pengamatan dari tahun 2014-2016, rata-rata nilai modal intelektual setiap perusahaan sebesar 1,2212 atau 122,12\%. Modal intelektual dikatakan baik jika perusahaan mampu mengelola aset dengan baik dan mampu menekan biaya operasional sehingga dapat meningkatkan nilai tambah dari hasil kemampuan modal intelektual perusahaan. Hal ini menunjukkan bahwa kemampuan modal intelektual yang tinggi, maka biaya secara efisien dapat dikelola. 
Variabel independen profitabilitas diperoleh nilai rata-rata sebesar $-3,1339$ dengan standar deviasi sebesar 0,83084. Nilai tersebut menunjukkan bahwa selama periode pengamatan dari tahun 2014-2016, rata-rata perolehan profitabilitas (ROE) perusahaan adalah sebesar $-3,1339$ atau $-313,39 \%$. Hal tersebut menunjukkan bahwa rata-rata profitabilitas perusahaan BUMN di BEI masih tergolong rendah.

Tabel 5.

Hasil Statistik Deskriptif

\begin{tabular}{|l|r|r|r|}
\hline & \multicolumn{1}{|c|}{ Mean } & Std. Deviation & \multicolumn{1}{|c|}{ N } \\
\hline NP (Y) & .7859 & .61389 & 49 \\
\hline MI (X1) & 1.2212 & .32467 & 49 \\
\hline Profit (X2) & -3.1339 & .83084 & 49 \\
\hline
\end{tabular}

Sumber: data diolah (2017)

\section{Menguji Koefisien Determinasi}

Besarnya nilai koefisien determinasi pada model regresi berganda ditunjukkan pada nilai Adjusted R Square. Hasil pengujian koefisien determinasi dapat dilihat pada Tabel 6. Berdasarkan pengujian tersebut diketahui nilai Adjusted $\mathrm{R}$ Square sebesar 0,195 , hal ini berarti bahwa 19,5\% variasi Nilai Perusahaan yang dapat dijelaskan oleh variasi Modal Intelektual dan Profitabilitas, sedangkan sisanya $\quad 80,5 \% \quad$ (100\%$19,5 \%=80,5 \%$ ) dipengaruhi oleh faktor-faktor lain diluar model.

Tabel 6.

Uji Koefisien Determinasi

\begin{tabular}{|l|c|r|r|r|}
\hline \multicolumn{5}{|c|}{ (Model Summary) } \\
\hline Model & $\mathrm{R}$ & $\begin{array}{c}\mathrm{R} \\
\text { Square }\end{array}$ & $\begin{array}{c}\text { Adj. R } \\
\text { Square }\end{array}$ & $\begin{array}{c}\text { Std. Error of } \\
\text { the Estimate }\end{array}$ \\
\hline 1 & $.478^{\mathrm{a}}$ & .228 & .195 & .55085 \\
\hline
\end{tabular}

Sumber: data diolah (2017)

\section{Uji Signifikansi Simultan (Uji F)}

Pengujian secara bersama-sama dilakukan untuk menguji pengaruh modal intelektual dan profitabilitas secara simultan terhadap nilai perusahaan. Hasil pengujian signifikansi simultan (uji statistik F) dapat dilihat pada Tabel 7.

Berdasarkan uji ANOVA atau $\mathrm{F}$ test bahwa nilai $F$ hitung sebesar 6,808 dengan probabilitas 0,003. Karena $F$ hitung lebih besar dari $F$ tabel $(6,808>3,158)$ dan probabilitas jauh lebih kecil dari 0,05, maka model regresi ini dapat digunakan untuk memprediksi nilai perusahaan. Nilai $F$ hitung $>$ F tabel $(6,808>3,158)$ juga menyatakan bahwa hipotesis nol ditolak $\left(\mathrm{H}_{0}\right.$ ditolak, dan $\mathrm{H}_{\mathrm{a}}$ diterima). Artinya, secara bersama-sama variabel independen; modal intelektual $\left(X_{1}\right)$ dan profitabilitas $\left(X_{2}\right)$ berpengaruh terhadap nilai perusahaan $(\mathrm{Y})$.

Tabel 7.

Uji Signifikansi Simultan

\begin{tabular}{|l|l|r|r|r|r|r|}
\hline \multicolumn{7}{|l|}{ ANOVA $^{2}$} \\
\multicolumn{2}{|l|}{ Model } & $\begin{array}{c}\text { Sum of } \\
\text { Square }\end{array}$ & df & $\begin{array}{c}\text { Mean } \\
\text { Square }\end{array}$ & F & Sig. \\
\hline \multirow{2}{*}{1} & Regression & 4.131 & 2 & 2.066 & 6.808 & $.003^{b}$ \\
\cline { 2 - 7 } & Residual & 13.958 & 46 & .303 & & \\
\cline { 2 - 7 } & Total & 18.089 & 48 & & & \\
\hline
\end{tabular}

Sumber: data diolah (2017)

\section{Uji Signifikansi Parsial (Uji t)}

Uji ini dilakukan untuk menguji modal intelektual $\left(X_{1}\right)$ dan profitabilitas $\left(X_{2}\right)$ secara parsial terhadap nilai perusahaan $(Y)$. Berhubung penelitian ini menggunakan metode sensus, maka tidak dilakukan uji signifikansi tehadap nilai koefisien tersebut, karena nilai koefisien regresi yang diperoleh adalah nilai koefisien regresi yang sesungguhnya dari populasi. Hasil pengujian signifikansi secara parsial dapat dilihat pada Tabel 8.

Tabel 8.

Uji Signifikansi Parsial

\begin{tabular}{|l|l|r|r|r|r|r|}
\hline \multicolumn{7}{|c|}{ Coefficients $^{\mathrm{a}}$} \\
\hline \multirow{2}{*}{ Model } & \multicolumn{1}{|c|}{$\begin{array}{c}\text { Unstandardized } \\
\text { Coefficients }\end{array}$} & $\begin{array}{c}\text { Std. } \\
\text { Coeff }\end{array}$ & $\mathrm{t}$ & Sig. \\
\cline { 2 - 5 } & \multicolumn{1}{c|}{$\mathrm{B}$} & Std.Error & Beta & & \\
\hline \multirow{2}{*}{1} & Cnstant & 1.640 & .549 & & 2.987 & .005 \\
\cline { 2 - 7 } & MI & .142 & .266 & .075 & .532 & .597 \\
\cline { 2 - 7 } & Profit & .328 & .104 & .443 & 3.150 & .003 \\
\hline
\end{tabular}

Sumber: data diolah (2017)

Berdasarkan uji $t$ dapat disimpulkan bahwa nilai beta $(\beta)$ untuk variabel modal intelektual $\left(X_{1}\right)$ adalah sebesar 0,142 . Sesuai dengan hipotesis yang diajukan maka $\mathrm{H}_{0}$ ditolak, dan $\mathrm{H}_{\mathrm{a}}$ diterima. Artinya, secara parsial variabel independen modal intelektual $\left(X_{1}\right)$ berpengaruh terhadap nilai perusahaan $(\mathrm{Y})$. Begitu juga variabel profitabilitas $\left(\mathrm{X}_{2}\right)$ memiliki nilai beta sebesar 0,328. Nilai tersebut menunjukkan hipotesis $\mathrm{H}_{0}$ ditolak, dan $H_{a}$ diterima. Artinya, secara parsial variabel profitabilitas $\left(X_{2}\right)$ berpengaruh terhadap nilai perusahaan (Y).

Model Regresi 
Model regresi dalam penelitian ini menggunakan model logaritma natural (Ln) dikarenakan data yang dipakai tidak berdistribusi normal, sehingga harus melewati proses transformasi data untuk mendapatkan distribusi yang diharapkan. Hasil pengujian hipotesis menggunakan model regresi berganda dengan logaritma natural (Ln) dapat dilihat pada persamaan berikut ini:

$\operatorname{Ln} Y=\operatorname{Ln} b 0+b 1 \operatorname{Ln} X_{1}+b 2 \operatorname{Ln} X_{2}+\varepsilon$ Berdasarkan persamaan regresi tersebut diketahui bahwa konstanta $(\alpha)$ sebesar 1,640 yang berarti apabila modal intelektual dan profitabilitas dianggap konstan, maka besarnya nilai perusahaan pada perusahaan BUMN yang terdaftar di Bursa Efek Indonesia periode 2014-2016 adalah sebesar 1,640 satuan.

\section{Hasil Pengujian Hipotesis}

\section{1) Pengaruh Modal Intelektual terhadap Nilai Perusahaan}

Hasil pengujian hipotesis menunjukkan bahwa modal intelektual berpengaruh positif terhadap nilai perusahaan yang ditandai dengan nilai koefisien regresi sebesar 0,142 $\left(\beta_{1}>0\right)$. Pengaruh positif tersebut bermakna bahwa modal intelektual memiliki pengaruh yang searah dengan nilai perusahaan. Semakin besar jumlah modal intelektual, maka akan semakin tinggi nilai perusahaan. Sebaliknya, semakin kecil jumlah modal intelektual, maka akan semakin rendah nilai perusahaan. Namun pengaruh tersebut tidak signifikan, ditandai dengan nilai signifikansi sebesar 0,597 $(0,597>0,05)$ pada taraf signifikansi $95 \%$.

Hasil penelitian ini konsisten dengan hasil penelitian yang dilakukan oleh Wahyuni (2013), Randa dan Solon (2012) serta putra (2012) dimana hasil penelitiannya menemukan bahwa terdapat hubungan yang positif antara modal intelektual dengan nilai perusahaan.

\section{2) Pengaruh Profitabilitas terhadap Nilai Perusahaan}

Pengujian hipotesis menunjukkan bahwa profitabilitas berpengaruh positif dan signifikan terhadap nilai perusahaan yang ditandai dengan nilai koefisien regresi sebesar 0,328 $\left(\beta_{2}>0\right)$ dan signifikansi sebesar
$0,003(0,003<0,05)$. Pengaruh positif tersebut bermakna bahwa profitabilitas memiliki pengaruh yang searah dengan nilai perusahaan. Semakin besar tingkat profitabilitas, maka akan semakin tinggi nilai perusahaan yang diperoleh. Sebaliknya, semakin kecil tingkat profitabilitas, maka semakin rendah nilai perusahaan yang diperoleh.

Hasil penelitian ini masih konsisten dengan hasil penelitian Soliha dan Taswan (2008), Wahyuni (2013) serta Ayuningtias dan Kurnia (2013) yang menemukan bahwa terdapat hubungan yang positif antara profitabilitas dengan nilai perusahaan.

3) Pengaruh Modal Intelektual dan Profitabilitas terhadap Nilai Perusahaan

Hasil pengujian hipotesis menunjukkan bahwa modal intelektual dan profitabilitas secara bersama-sama berpengaruh terhadap nilai perusahaan yang ditandai oleh nilai koefisien regresi tidak sama dengan nol $\left(b_{i} \neq 0\right)$. Besarnya pengaruh modal intelektual dan profitabilitas terhadap nilai perusahaan adalah 19,5\%, hal ini ditunjukkan oleh nilai Adjusted $R$ Square = 0,195 atau 19,5\% yang berarti nilai perusahaan dipengaruhi oleh modal intelektual dan profitabilitas sebesar $19,5 \%$, sementara $80,5 \%$ dipengaruhi oleh variabel lain yang tidak dimasukkan dalam penelitian.

Pengaruh yang rendah tersebut yaitu hanya 19,5\% menunjukkan bahwa modal intelektual dan profitabilitas secara bersamasama belum sepenuhnya menjadi faktor utama yang menentukan nilai perusahaan pada BUMN yang terdaftar di BEI. Hal ini disebabkan masih banyaknya faktor-faktor lain yang tidak dimasukkan dalam model penelitian ini yang berperan dalam menjelaskan nilai perusahaan, yang ditunjukkan oleh sisa nilai koefisien determinasi sebesar 80,5\%.

\section{KESIMPULAN}

\section{Kesimpulan}

Modal intelektual dan profitabilitas secara bersama-sama berpengaruh terhadap nilai perusahaan pada perusahaan BUMN yang terdaftar di BEI periode 2014-2016. 
Modal intelektual juga berpengaruh positif namun tidak signifikan terhadap nilai perusahaan pada perusahaan BUMN yang terdaftar di BEI periode 2014-2016.

Begitu juga profitabilitas berpengaruh positif dan signifikan terhadap nilai perusahaan pada perusahaan BUMN yang terdaftar di BEI periode 2014-2016.

\section{IMPLIKASI \& KETERBATASAN Keterbatasan}

Penelitian ini hanya fokus pada perusahaan BUMN yang terdaftar di BEI saja. Variabel independen yang digunakan dalam penelitian ini hanya modal intelektual dan profitabilitas sehingga masih memungkinkan adanya variabel lain yang diduga mempunyai pengaruh lebih besar terhadap nilai perusahaan.

Untuk periode data yang digunakan baru tiga tahun, sehingga temuan dalam penelitian ini belum bisa melihat kecenderungan dalam jangka panjang.

\section{Saran}

Penelitian selanjutnya diharapkan dapat memperluas subjek penelitian, tidak hanya pada perusahaan BUMN yang terdaftar di BEI saja karena memungkinkan ditemukannya hasil dan kesimpulan yang berbeda jika dilakukan pada subjek penelitian yang berbeda.

Begitu juga dengan variabel yang digunakan selanjutnya dapat menambah variabel selain modal intektual dan profitabilitas, yang diduga turut mempengaruhi nilai perusahaan, seperti: leverage, voluntary disclosure, ukuran perusahaan, earning growth, dan lain-lain.

Penelitian selanjutnya juga dapat menggunakan periode data lebih dari tiga tahun agar hasilnya dapat menggambarkan kondisi yang ada dan memberikan hasil yang lebih komprehensif.

\section{DAFTAR PUSTAKA}

Ayuningtias, Dwi dan Kurnia. 2013. Penggaruh Profitabilitas Terhadap Nilai Perusahaan: Kebijakan Deviden Dan
Kesempatan Investasi Sebagai Variabel Antara. Jurnal Ilmu dan Riset Akuntansi, Vol. 1. No. 1: 37-57.

Bontis, N., W.C.C. Keow and S, Richardson. 2000. Intellectual Capital and Business Performance in Malaysian Industries. Journal of Intellectual Capital, 1 (1): 85100.

Chen, M.,S, Cheng and Y, Hwang. 2005. An Empirical Investigation of the Relationship Between Intelellectual Capital and Firm's Market Value and Financial Performance. Journal of Intellectual Capital, Vol.6 No.2 : 159-176.

Jusriani, Ika Fanindya. dan S.N. Raharjo. 2013.

Analisis Pengaruh Profitabilitas, Kebijakan Deviden, Kebijakan Hutang, dan Kepemilikan Manajerial Terhadap Nilai Perusahaan (Studi Empiris pada Perusahaan Manufaktur yang Terdaftar di BEI 2009-2011). Diponegoro Journal of Accounting, Vol. 2. No. 2: 1-10.

Pulic, A. 1998. Measuring the Performance of Intellectual Potential in Knowledge Economy; Available at: www.measuringip.at/Opapers/Pulic/Vaictxt.html

Putra, I. Gede Cahyadi. 2012. Pengaruh Modal Intelektual Pada Nilai Perusahaan Perbankan di BEI. Jurnal Ilmiah Akuntansi dan Humanika JINAH, Vol. 2. No.1: 1-22.

Randa, Fransiskus dan S.A, Solon. 2012. Pengaruh Modal Intelektual Terhadap Nilai Perusahaan. Jurnal Sistem Informasi Manajemen dan Akuntansi, Vol. 10. No. 1: 24-47.

Sawarjuwono, T. \& P.A, Kadir. 2005. Intellectual Capital: Perlakuan, Pengukuran, dan Pelaporan. Jurnal Akuntansi dan Keuangan, 5 (1): 35-57.

Soliha, E. dan Taswan. 2002. Pengaruh Kebijakan Hutang terhadap Nilai Perusahaan serta Beberapa Faktor yang Mempengaruhinya. Jurnal Bisnis dan Ekonomi, Vol. 9. No. 2: 149-163.

Sujoko dan U. Soebiantoro. 2007. Pengaruh Struktur Kepemilikan Saham, Leverage, Faktor Intern dan Faktor Ekstern terhadap Nilai Perusahaan. Jurnal Manajemen dan Kewirausahaan, Vol. 9. No. 1: 41-48. 
Ulum, I. 2008. Intellectual Capital Performance Sektor Perbankan di Indonesia. Jurnal Akuntansi dan Keuangan, 10 (2): 77-84.

Wahyuni, Eka Suci. 2013. Pengaruh Modal Intelektual dan Profitabilitas Terhadap Nilai Perusahaan (Studi pada Perusahaan Manufaktur di BEI). Tesis Program S2 Magister IImu Akuntansi Universitas Syiah Kuala. Tidak Dipublikasika 